\title{
Management of major field insect pests and yield of cowpea (Vigna unguiculata (L) walp) under calendar and monitored application of synthetic chemicals in Asaba, southern Nigeria
}

\author{
E. O. Egho \\ Department of Agronomy, Faculty of Agriculture, Asaba Campus, Delta State University \\ ABSTRACT
}

\begin{abstract}
The management of major field insect pests of cowpea under calendar and monitored sprays of cypermethrin was studied. The major insect pests studied were the cowpea aphid, Aphis craccivora Koch, legume bud thrips Megalurothrips sjostedti Tryb, legume pod borer, Maruca vitrata Fab. and pod sucking bugs. Influence of insect pest management on yield was also determined. The calendar sprays consisted of 7 days' spray intervals carried out 5 times and 10 days' spray intervals, carried out 4 times. Monitored spray was carried out only when insect pest infestation/damage reached or exceeded the action threshold. The experiments were conducted in the Teaching and Research Farms of the Agronomy department, Asaba Campus, Delta State University, Nigeria. Comparison of insect pests and grain yield from the calendar and monitored spray treatments was made if differences existed among them. Results indicated that all the cypermethrin treatments effectively controlled $M$. sjostedti, $M$. vitrata, flower bud thrip population and pod sucking bugs when compared to control in the early season. There was however, no significant difference $(P>0.05)$ in calendar and monitored sprays. Similar observation was made for grain yield. In the late season, all treatments significantly $(P<0.05)$ controlled pest population/damage on cowpea. Grain yield increase was similarly recorded but no differences among the treatments. Cowpea growers sometimes apply insecticides as many as 8 to 10 times to control insect pests during the growing season; the study here provides evidence (1) that 10 days' interval spray and monitored spray can be as profitable as 7 days' interval spray in cowpea production and (2) this could reduce the number of chemical application, save cost as well as environmental pollution and hazards to consumers.
\end{abstract}

Keywords: Cowpea, insect pests, calendar and monitored sprays, cypermethrin, Asaba, Southern Nigeria.

\section{INTRODUCTION}

A major food crop grown in many African countries is the legume cowpea (Vigna unguiculata (L) Walp). Cowpea grains are well known for their protein content (20-30\%) and they are source of cheap plant protein (Dolvo et al., 1976; Okigbo, 1978; Johnson et al., 1983; IITA, 1984; Anderson, 1985) to people who hardly can afford animal protein derived from meat, fish, milk and eggs. Cowpea is rich in minerals, fats, oils and vitamins. In livestock industries, it serves as feed when mixed with cassava (Job et al., 1983). It is a delicacy in Nigeria, consumed as moi-moi and akara (Adams, 1984). In southern Nigeria, people eat it on regular basis in the West (Williams, 1974) and in the East (King et al., 1985).

Cowpea is cultivated in the tropical and subtropical regions of the world and it grows in diverse soil types and climatic conditions (Alghali, 1991). It is grown mainly in Northern Nigeria but its cultivation has recently spread to Southern Nigeria where it is cultivated in the West and East (Ejiga, 1979; FOS, 1995; Emosairue et al., 2004).

Yields are however, generally low (Olatunde et al., 1991), sometimes total yield losses and crop failure occur (Singh and Jackai, 1985) due to the activities of a spectrum of insect pests which ravage the crop in the field at different growth stages (Singh and ven Emdem, 1979). The major insect pests which severely damage cowpea during all growth stages are the cowpea aphid (Aphis craccivora Koch), foliage beetles (Ootheca sp, Medythia spp), the flower bud thrips (Megalurothrips sjostedti Trybom) the legume pod borer (Maruca vitrata Fabricius) and the sucking bug complex, of which Clavigralla spp, Anoplocnemis spp, Riptortus spp, Mirperus spp, 
Nezara viridula Fab and Aspavia armigera $\mathrm{L}$ are most important and are prevalent. Without their control, reasonable grain yield cannot be obtained (Jackai and Daoust, 1986; Suh et al., 1986). Several control measures are available (Jackai, 1985) but chemicals are most effective, giving several fold increase in grain yield (Jackai, 1993). Sometimes, however, farmers spray their farms as many as eight to ten times during the growing season (Omongo et al., 1998).

Because of the danger of the use of chemicals such as environmental pollution, toxicity to mammals, hazards to users and consumers (Alabi et al., 2003), alternative control measures are being sought. Total abandonment of chemicals could however, spell doom to man as this will worsen the present food situation (Stern, 1973). Chemicals could be judiciously used in consonance with other control measures so as to minimise the large number of sprays in farms. Various synthetic chemicals are available in the market and new products with different trade names abound yearly. Their efficacy against the wide spectrum of cowpea pests are being tested.

This paper reports on the benefits of calendar (fixed number of sprays) and monitored spray (sprayed at specific times) application of cypermethrin (conventional chemical) on major pests and yield of cowpea in the early and late cropping seasons at Asaba, Southern Nigeria.

\section{MATERIALS AND METHODS}

The study was conducted during the two cropping seasons (early and late) of 2005, in the Research and Teaching Farms of the Agronomy Department, Asaba Campus, Delta State University, Oshimili South LGA, Delta State, Nigeria. The land was prepared by ploughing and harrowing with a tractor in the early season while it was prepared manually using shovels and hoes in the late season. The experimental plots measured each $5 \mathrm{~m} \times 3 \mathrm{~m}$ with inter-plot space of $1.5 \mathrm{~m}$. Ife brown seeds (obtained from the International Institute of Tropical Agriculture (IITA) Ibadan, Nigeria, were planted at planting space of $60 \mathrm{~cm} \times 30 \mathrm{~cm}$ (Remison, 1978e). Planting in the early season took place on 29th May and 17th September, for the late season. Three seeds were planted per hole and seeds that did not sprout were replaced 4 days after planting. The seedlings were thinned to two plants per stand, 10 days after sprouting. Each plot consisted of 6 rows of 36 plants. Regular weeding of the farm till maturity was done. Cypermethrin, a conventional chemical was applied on the crops, starting from 25 days after planting (25 DAP). The experiment consisted of 4 treatments and 3 replicates fitted into a randomised complete block design. The treatments were as follows:

(i) Calendar spray at 7 days' intervals, carried out 5 times;

(ii) Calendar spray at 10 days' intervals carried out 4 times;

(iii) Monitored spray, carried out only when insect pests damage/infestation reached or exceeded the action threshold, and

(iv) Plots without chemical protection (control).

The effect of chemical application on 4 key insect pests of cowpea and influence on yield was observed.

Insect pest observations and data collection

Insect Infestation/Damage: Aphis craccivora: Observations commenced 26 DAP, at 7 days' intervals, between 8 and 10 a.m. Twenty cowpea stands from the two middle rows of each plot were randomly selected and tagged. Each stand was then inspected for aphid infestation. The colony size was visually scored, based on a scale of 10 points (Table 1). The score for each stand was recorded and the mean calculated. Six observations were made from each treatment.

Table 1. Scale for rating aphid infestation on cowpea

\begin{tabular}{lll}
\hline Rating & Number of aphids & Appearance \\
\hline 0 & 0 & no infestation \\
1 & $1-4$ & a few individual aphids \\
3 & $5-20$ & a few isolated colonies \\
5 & $21-100$ & several small colonies \\
7 & $101-500$ & large isolated colonies \\
9 & $>500$ & large continuous colonies \\
\hline
\end{tabular}

Source: Litsinger et al. [1977] 
Table 2. Scale for rating flower bud thrips infestation on cowpea

\begin{tabular}{|c|c|c|c|}
\hline Rating & \multicolumn{3}{|l|}{ Appearance } \\
\hline 1 & \multicolumn{3}{|c|}{ no browning/drying (i.e scaling) of stipules, leaf or flower buds; no bud abscission } \\
\hline 3 & \multicolumn{3}{|c|}{ initiation of browning of stipules, leaf or flower buds; no bud abscission } \\
\hline 5 & \multicolumn{3}{|c|}{ distinct browning/drying of stipules and leaf or flower buds; some bud abscission } \\
\hline 7 & \multicolumn{3}{|c|}{$\begin{array}{l}\text { serious bud abscission accompanied by browning/drying of stipules and buds; non elongation } \\
\text { of peduncles }\end{array}$} \\
\hline 9 & \multicolumn{3}{|c|}{$\begin{array}{l}\text { very severe bud abscission, heavy browning, drying of stipules and buds; distinct non- } \\
\text { elongation of (most or all) peduncles. }\end{array}$} \\
\hline \multicolumn{4}{|c|}{ After Jackai and Singh (1988) } \\
\hline \multicolumn{2}{|c|}{ Pod load (PL) } & \multicolumn{2}{|c|}{ Pod damage (PD) } \\
\hline Rating & Degree of podding & Rating & $\%$ \\
\hline 1 & most (<60\% peduncles bare (i.e. no pods) & 1 & $0-10$ \\
\hline \multirow[t]{2}{*}{3} & \multirow[t]{2}{*}{$31-50 \%$ peduncles bare } & 2 & $11-20$ \\
\hline & & 3 & $21-30$ \\
\hline \multirow[t]{3}{*}{5} & \multirow[t]{3}{*}{$16-30 \%$ peduncles bare } & 4 & $31-40$ \\
\hline & & 5 & $41-50$ \\
\hline & & 6 & $51-60$ \\
\hline \multirow[t]{2}{*}{7} & \multirow[t]{2}{*}{ Up to $15 \%$ peduncles bare } & 7 & $61-70$ \\
\hline & & 8 & $71-80$ \\
\hline 9 & Occasional bare peduncles & 9 & $81-100$ \\
\hline
\end{tabular}

After Jackai and Singh (1988)

Megalurothrips sjostedti: Observations commenced at 30 DAP at the intervals of 6 days between 8 and 10 a.m. From twenty randomly tagged cowpea stands in the two middle rows, $M$. sjostedti damage to cowpea was rated visually on a 1-9 point scale based on known symptoms - browning/drying of stipules, leaf buds, flower bud abscission, etc. (Table 2). The score for each plant was recorded and the mean scores for the twenty plants calculated. Five observations were made.

Damage to flowers by Maruca: Infestation of cowpea flowers by Maruca vitrata larvae was assessed at 45 DAP. Twenty flowers were randomly selected from the two outer cowpea rows. The flowers were carefully opened and examined on the spot for Maruca damage from 3.00 - 5.00 p.m. Presence of holes or larvae in a flower was used as index of Maruca infestation. Observation was done four times, at 5 days' intervals. The mean score for the 20 flowers was calculated and recorded.

Pod sucking bugs: Observations commenced at 45 DAP at 5 days' intervals. From the two middle rows of cowpea plot, observations were made between 8.00 10.00 a.m. Pod sucking bugs (PSBs) that rested on the plant were counted and recorded. All bugs were counted together since their damage are similar and all bug species and stages beyond second nymphal instar were counted Afun et al., 1991)
Yield and yield components: Grain yield: At maturity, 65-70 DAP, pods from the 2 central rows in each plot were harvested with hands into labelled polythene bags. The pods were sundried for one week and then shelled. The dry grain yields in each plot were weighed with a weighing balance (triple beam balance, Haus Model) and the weight recorded. The yield per plot was extrapolated to $\mathrm{Kg}$ $\mathrm{ha}^{-1}$.

Grain weight: One hundred seeds were picked from the grains in each plot; they were weighed and the weights recorded.

Number of pods per plant: At 60 DAP, the number of pods per plant was determined from the two middle rows of each plot. One metre length of cowpea plants was taken with 1 metre ruler. The length was marked with 2 sticks. Cowpea plants and their pods that fell within this distance were counted. The number of pods were then divided by the number of cowpea plants and the value recorded.

Number of pods/plants $=\quad$ Number of pods Number of plants

Pod load and pod damage by Maruca vitrata: Pod load and pod damage by $M$. vitrata were assessed in the field by visual rating on a scale of 1-9 (Jackai and Singh, 1988) (Table 3). Assessment was done at 60 DAP when the pods were fully filled and matured but still green. Holes and presence of frass on pods and 
sticking of pods were used as damage index by Maruca.

Pod and seed damage by pod sucking bugs: This was assessed by examining the pods and seeds in the laboratory. Cowpea pods in the two middle rows in each plot were harvested at maturity and kept in labelled medium size polythene bags according to plot number. They were sun-dried for one week. From each of the bags, 20 pods were hand-picked randomly. Each pod was then carefully opened with hand. The number of seeds per pod, aborted seeds per pod, wrinkled seeds per pod and seeds with feeding lesions per pod were observed, recorded and the mean calculated.

Pod length: Pods in the 2 central rows of each plot were harvested at 65-70 DAP with hands and kept in labelled black polythene bags (according to plot number). They were sundried for one week and from each of the labelled bags, 20 pods were hand picked randomly. Each was then measured with a flexible thread to determine its length. The mean value of pod length for the 20 pods was calculated.

Pod evaluation index (Ipe): This was assessed using the formula below:

PL $\times(9$ - PD) where PL is pod load and PD pod damage (Jackai and Singh, 1988).

Data for insect observation, yield and yield related components were subjected to analysis of variance (ANOVA) and significant means separated by Fisher's Least Significant Difference Test (LSD), at $5 \%$ level of significance.

\section{RESULTS}

The effects of cypermethrin on the management of major insect pests of cowpea under calendar and monitored application during the early and late seasons experiments at Asaba are presented in Tables 4.

All the major insects except $A$. craccivora were encountered on the crop during the early season in the study area. The treatments did not significantly ( $P$ $>0.05)$ reduce the damage to flower buds by $M$. sjostedti (Table 4). However, plots without insecticidal treatment had slightly higher damage than those which received insecticidal treatments. This situation was different with the thrip population. All the treatments significantly $(P<0.05)$ reduced the insect population when compared with the control. Similarly, calendar spray at 7 - days' intervals was significantly more effective in reducing the thrips population when compared with monitored insecticidal application. However, calendar spray at 7 days' intervals was not significantly different from calendar spray at 10 days' intervals.

The two calendar treatments (7-days' and 10-days' intervals) significantly reduced $M$. vitrata infestation/damage compared with the control. The results showed that the two calendar treatments, were not significantly different in their effectiveness. However, the 7 days' interval spray was significantly more effective than the monitored treatment. All the insecticide treatments were not significantly different in reducing the population of pod sucking bugs (PSB) when compared with the control. Pod sucking bug population was however, slightly higher in the control.

All the major insect pests were recorded on the crop during the late season in the study area. CA.S7 significantly $(P<0.05)$ reduced $A$. craccivora population when compared with the control. CA. S10 and monitored sprays were similar in their effect on A. craccivora (Table 4). All the treatments significantly $(P<0.05)$ reduced the damage by $M$. sjostedti when compared with the control. The calendar sprays at 7 and 10 days' intervals and the monitored sprays were similar in their effect on cowpea damage by $M$. sjostedti.

For the flower bud thrips, all treatments significantly $(P<0.05)$ reduced the insect population when compared with the control. The 7 and 10 days' sprays and monitored sprays did not show significant differences between them in reducing the thrip population. On Maruca, the 7 and 10 days' sprays significantly reduced the insect population when compared with the control and MOS plots. For PSB, there was no significant difference among the chemically treated plots and when compared with the control.

Comparing the two seasons (Table 5), late season $A$. craccivora population was significantly $(P<0.05)$ higher than early season. There was no significant difference in damage to cowpea by $M$. sjostedti in the two seasons. However, damage was slightly higher in the late season than early (Table 5). The population of flower bud thrips was significantly $(P<0.05)$ higher during the late season than the early planting season. Maruca vitrata, damage to cowpea flowers was 
significantly higher $(P<0.05)$ in the early season when compared with the late season. Pod sucking bugs population in the late season population was significantly $(P<0.05)$ higher when compared with the early season population.

The effect of cypermethrin on cowpea yield and yield related components in the early and late seasons in Asaba is presented in Table 6.

In the early season, grain yield from insecticide protected plots were not significantly different $(P>$ 0.05 ) from plots without chemical protection. Also, all chemically treated plots were not significantly different. However, plots which were sprayed every 10 days' intervals had slightly higher yield than calendar spray at 7 days' intervals and monitored spray (Table 6). For the 100 seeds weight, there was no significant difference among the treatments and when compared with control. Yield related components such as number of pods/plants, number of seeds/pod, pod load, pod damage, pod evaluation index and wrinkled seeds per pod were not significantly different in the various treatments in the early season. However, others such as pod length, aborted seeds/pod and seeds with feeding lesions showed significant difference among the treatments (Table 6).

In the late season, yields in the various treatments significantly $(P<0.05)$ increased when compared with the control. The 100 seed weights were not significantly different when weights of seeds from insecticide protected plots were compared with those from the plots without insecticide protection. In the case of number of pods per plant, all treatments resulted in significantly $(P<0.05)$ higher number of pods when compared with control. There were no significant differences among the insecticidal treatments. In the case of pod length, the various treatments did not significantly $(P>0.05)$ increase pod length when compared with the control. With respect to the number of seeds per pod, only MOS treated plots was significantly higher than the control while others were not significantly different from control. With respect to pod load, the various treatments significantly $(P<0.05)$ increased pod load when compared with the control. Also, the treatments significantly $(P<0.05)$ reduced pod damage when compared with the control. Similarly, Ipe values in the various treatments showed that the treatments significantly $(P<0.05)$ improved the pods compared with the control. For aborted seeds per pod however, the insecticide protected plots did not significantly prevent seed abortion per pod when compared with the control. Among the treatments, there was no significant difference. The pods in monitored plots had slightly less abortion of seeds than the other treatments. In the case of wrinkled seeds per pod, insecticide protected plots did not significantly $(P>0.05)$ reduce the wrinkling of seeds per pod when compared with the control. However, wrinkled seeds were slightly more in non-protected plots than seeds from protected plots. On seeds with feeding lesions, there was no significant difference between chemically protected plots and the unprotected plots.

The seasonal effect on cowpea yield and yield related components under the calendar and monitored application of conventional insecticide during the early and late seasons in Asaba is presented in Table 7.

Grain yields in the early and late seasons were not significantly different; however late season yields were slightly higher than the early season yield. For 100 seed weight, late season grains had higher weight which were significantly $(P<0.05)$ heavier than early season grains. Similarly, the number of pods per plant in the late season, were significantly higher than early season. With pod length, early season pods had lengths that were significantly $(P<$ 0.05) longer than the late season pod lengths. On number of seeds per pod, early season cowpea had more seeds in their pods and this was significantly higher than the late season cowpea pods. With pod load, late season load was significantly higher than early season. In the case of pod damage, there was no significant difference in the two seasons. However, damage to pods was slightly more in early season when compared with the late season. For pod evaluation index, late season had Ipe value that was significantly higher than the early season Ipe value. For aborted seeds per pod, there was no significant difference between the two seasons. Early season however, had slightly more aborted seeds than the late season. On wrinkled seeds per pod, there was no significant difference between the two seasons but seeds wrinkled in the late season were slightly more than the early season. Similar trend was encountered with seeds with feeding lesions, i.e. no significant difference in the two seasons. 
Am. J. Sci. Ind. Res., 2011, 2(4): 592-602

Table 4: Effect of calendar and monitored application of synthetic insecticide (cypermethrin) on the major insect pests of cowpea in the early and late seasons at Asaba.

\begin{tabular}{|c|c|c|c|c|c|c|c|}
\hline & Treatments & $\begin{array}{l}\text { Aphis } \\
\text { craccivora } \\
\text { (rating) }^{\star \star}\end{array}$ & $\begin{array}{l}\text { Megalurothrips } \\
\text { sjostedti } \\
\text { (rating) }\end{array}$ & $\begin{array}{l}\text { Flower } \\
\text { thrips* } \\
\text { (actual } \\
\text { counting) }\end{array}$ & bud & $\begin{array}{l}\text { Maruca } \\
\text { vitrata* } \\
\text { (actual } \\
\text { counting) }\end{array}$ & $\begin{array}{l}\mathrm{PSB}^{\star \star} \\
\text { (actual counting) }\end{array}$ \\
\hline \multirow{5}{*}{ 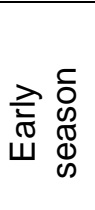 } & CONTROL & & 1.49 & 2.90 & & 0.24 & 0.22 \\
\hline & CA.S7 & & 1.36 & 0.74 & & 0.08 & 0.00 \\
\hline & CA.S10 & & 1.33 & 1.13 & & 0.13 & 0.00 \\
\hline & MO.S & & 1.40 & 1.78 & & 0.16 & 0.11 \\
\hline & $\operatorname{LSD}(0.05)$ & & NS & 0.87 & & 0.09 & NS \\
\hline \multirow{5}{*}{ 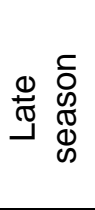 } & CONTROL & 1.22 & 2.17 & 8.39 & & 0.18 & 3.00 \\
\hline & CA.S7 & 0.00 & 1.33 & 3.61 & & 0.08 & 3.33 \\
\hline & CA.S10 & 0.44 & 1.33 & 3.92 & & 0.08 & 3.78 \\
\hline & MO.S & 0.44 & 1.33 & 4.76 & & 0.10 & 2.22 \\
\hline & $\operatorname{LSD}(0.05)$ & 0.78 & 0.53 & 1.47 & & 0.08 & NS \\
\hline
\end{tabular}

CA.S7- Calendar spray at 7 days' intervals, CA.S10 - Calendar spray at 10 days' intervals MOS - Monitored spray, N.S - Not significant

* Means of 20 flowers

** Number per 2 middle rows

Table 5: The seasonal effect of the application of cypermetrin on the major insect pests of cowpea at Asaba.

\begin{tabular}{llcrrr}
\hline Season & $\begin{array}{l}\text { Aphis } \\
\text { craccivora } \\
\text { (rating) }\end{array}$ & $\begin{array}{l}\text { Megalurothrips } \\
\text { sjostedti } \\
\text { (rating) }\end{array}$ & $\begin{array}{l}\text { Flower } \\
\text { thrips } \\
\text { (actual } \\
\text { counting) }\end{array}$ & $\begin{array}{l}\text { bud } \\
\text { Maruca } \\
\text { vitrata* } \\
\text { (actual } \\
\text { counting) }\end{array}$ & $\begin{array}{l}\text { PSB }^{\star *} \\
\text { (actual counting) }\end{array}$ \\
\hline Early & 0.00 & 1.40 & 1.64 & 0.15 & 0.08 \\
Late & 0.53 & 1.54 & 5.17 & 0.11 & 3.08 \\
LSD (0.05) & 0.30 & $\mathrm{NS}$ & 0.60 & 0.04 & 0.81 \\
\hline
\end{tabular}

* Means of 20 flowers $\quad$ ** Number per 2-middle rows NS-Not significant 
Am. J. Sci. Ind. Res., 2011, 2(4): 592-602

\begin{tabular}{llllllllll} 
Table 6: Effect of cypermethrin on yield and yield related components In the early and late seasons at Asaba \\
\hline
\end{tabular}

CA.S7 - Calendar spray at 7 days' intervals, CA.S10 - Calendar spray at 10 days' intervals, MOS - Monitored spray, N.S - Not significant

Table 7: The effect of early and late seasons on yield and yield related components from cowpea under the application of cypermethrin at Asaba

\begin{tabular}{|c|c|c|c|c|c|c|c|c|c|c|c|}
\hline Season & $\begin{array}{l}\text { Dry Grain } \\
\text { yield (kg } \\
\left.\text { ha }^{-1}\right)\end{array}$ & $\begin{array}{l}100 \text { seeds } \\
\text { wt(g) }\end{array}$ & $\begin{array}{l}\text { Number of } \\
\text { pods/ } \\
\text { plant } \\
\text { (approx) }\end{array}$ & $\begin{array}{l}\text { Pod length } \\
(\mathrm{cm})\end{array}$ & $\begin{array}{l}\text { Number of } \\
\text { seeds/pod }\end{array}$ & Pod load & $\begin{array}{l}\text { Pod } \\
\text { damage }\end{array}$ & $\begin{array}{l}\text { Pod } \\
\text { evaluation } \\
\text { index }\end{array}$ & $\begin{array}{l}\text { Aborted } \\
\text { seeds/pod }\end{array}$ & $\begin{array}{l}\text { Wrinkled } \\
\text { seeds/pod }\end{array}$ & $\begin{array}{l}\text { Seeds with feeding } \\
\text { lesions }\end{array}$ \\
\hline Early & 698.70 & 12.67 & 6.12 & 14.37 & 13.66 & 5.83 & 3.83 & 32.17 & 2.64 & 0.81 & 0.11 \\
\hline Late & 741.40 & 15.73 & 9.02 & 12.54 & 12.64 & 7.67 & 3.25 & 51.25 & 2.59 & 1.26 & 0.10 \\
\hline $\operatorname{LSD}(0.05)$ & NS & 0.50 & 1.47 & 0.46 & 0.54 & 1.30 & NS & 10.86 & NS & NS & NS \\
\hline
\end{tabular}

NS $=$ Not significant 


\section{DISCUSSION}

Aphis craccivora did not infest cowpea (Ife-brown, a highly susceptible cowpea variety to insect pests) in the early season (April-July) in the study area in all the plots. Consequently, the application of insecticide became unnecessary in the monitored spray plots against $A$. craccivora. Ofuya (1989) reported $A$. craccivora infestation on cowpea in the early season (April-July) in weed free cowpea plots in Akure located in another rain forest vegetation zone of Nigeria like Asaba. Similar report was given by Jackai et al. (1988) though, at low level of aphid infestation at this period. The result from this study is at variance with the above reports. The absence of $A$. craccivora could probably be ascribed to the following reasons: (a) the non-cultivation of cowpea in this zone for several years (b) weather factor which could have possibly hindered aphid migratory activity, as rains were heavy and frequent in this season. The absence of Aphis craccivora as indicated in this study agree with the findings of Degri and Hadi (2000) who reported from Bauchi, the absence of Aphis craccivora on field cowpea under heavy rain fed condition. Perhaps, A. craccivora would prefer a warm weather mixed with rains as encountered in the late cropping season in the area.

The study had revealed that the synthetic insecticide was effective on $M$. sjostedti and flower bud thrips population control since the unprotected plots had higher damage than insecticide protected plots. This result is consistent with reports that application of insecticides generally reduce cowpea pest infestation and markedly increase crop yields (Karungi et al., 2000; Jackai and Daoust, 1986). In eastern Uganda, large scale cowpea producers, sometimes apply insecticides as many as 8 - 10 times during the growing season to control pests (Isubikalu, 1998; Omongo et al., 1998). The results suggest that 10 days' interval insecticide application (4 times) can be as profitable as 7-days' interval application (5 times) in cowpea production and this could save cost, reduce environmental pollution and hazards to users and consumers. Similar trend was encountered in the impact of chemicals on $M$. vitrata and PSB. It further reveals that the monitored spray application was as beneficial as seven days and ten days' intervals application. These observations agree with Afun et al. (1991) who reported that there were no differences in chemical effect on damage by cowpea flower bud thrips when 7-days and 10-days' insecticide application on cowpea plots were compared with monitored spray plots.
In the late season, Aphis craccivora infested cowpea plants in all the plots as early as 2 weeks after planting. The appearance of aphids at this time, seems to suggest that the insect preferred a relatively warm and moist weather to establish on the crop. The CPM was not effective in reducing the aphid population. This result was not consistent with previous reports of the use of synthetic chemicals on aphid control. Probably, there was constant dilution and washing away of chemicals. Possibly too the canopy of cowpea and pod angles could have protected insect pests against chemicals (Jackai and Oyediran, 1991). The trend was however different with $M$. sjostedti. The chemical suppressed the insect damage on cowpea. The result was consistent with previous reports on thrips control with the use of synthetic pyrethroids. The results revealed that 10 days' spray and monitored spray would reduce insect damage and the number of insecticidal spray, as 7 days' spray. Similar trend was encountered with the CPM effectively controlling thrip population and Maruca damage to cowpea.

The similarity of the effect of the chemical on PSB population in the different treatments was probably due to population pressure of the insect on the crop, as at this time PSB was generally high in cowpea plots. IITA (1983) reported that PSB population was high in the second season of planting at Ibadan.

Comparing the two seasons, the results revealed that colonies of $A$. craccivora were better established in the late season than early season at Asaba. In the late season, there are less rains and more sunny days; possibly, these factors favour the rapid breeding of $A$. craccivora. Furthermore, the effect of rain drops to knock off the insect was reduced at this season when compared with the heavy rains in the early season. The more damage by $M$. sjostedti to cowpea in the late season than early was probably due to more thrip population encountered in this season than early season. The high population of thrip observed in the late season is consistent with Alabi et al. (2003) who in the second season recorded high thrips population on Kpodjiguegue and IT91K-180 at IITA Ibadan. Furthermore, warmer days could have made the insects more active and this increased their feeding activities, resulting in more damage in the late season than early. The more damage to cowpea flowers by $M$. vitrata in the early season than late is consistent with Afun et al. (1991) who reported that pod borer population /damage was more in the early season than late season. The more population of PSB's in the late season than early as 
indicated in the result was consistent with IITA (1983) that recorded high infestation of coreid bugs in the late season. The study also agreed with Dina (1982) who observed high infestation of coreid bugs in the late season in Ibadan.

During the early planting season, the cypermethrin application proved effective in controlling insect pests, judging from the yields per ha ${ }^{-1}$ - CA.S7 $\left(517.90 \mathrm{~kg} \mathrm{ha}^{-1}\right)$, CA.S10 (822.20 kg ha $\left.{ }^{-1}\right)$, MOS $\left(745.20 \mathrm{kgha}^{-1}\right)$. In the early season yield the different treatments manifested various levels of grain yields. From the data, the study indicates that 10 days' interval spray is as productive as 7 days' intervals spray and monitored sprays. The 10 days' spray intervals (carried out four times) had the advantages of reducing the number of sprays' and therefore cost. Yields from monitored plots also expressed similar opinion, that by proper monitoring of insect pests infestation before spraying it would reduce cost. Grain yields obtained in the early season study compared favourably with grain harvested from Bauchi, Northern Nigeria (Degri and Hadi, 2000) and Mokwa and Bida (Afun et al., 1991). The results showed that cowpea production could be profitable at Asaba during the early season. Earlier report, Karangi et al. (2000) indicated that planting at the onset of rains at $30 \times 20 \mathrm{~cm}^{2}$ or $60 \times 20 \mathrm{~cm}^{2}$ gave better yields. However, effective grain drying facilities must be put in place to sustain the good harvest.

Most of the yield related components such as seed weight, number of pods per plant, pod length, number of seeds per pod, pod load, pod damage, pod evaluation index and wrinkled seeds from the different treatments had values which suggest that the chemical variation, had little or no difference in yield output.

In the late season, grain yields from the various treatments in the study area were quite high as follows: CA.S7 $\left(843.00 \mathrm{~kg} \mathrm{ha}^{-1}\right)$, CA.S10 $(940.20 \mathrm{~kg}$ $\left.\mathrm{ha}^{-1}\right)$, MO S $\left(835.00 \mathrm{~kg} \mathrm{ha}^{-1}\right)$. The control had the least yield of $238.40 \mathrm{~kg} / \mathrm{ha}^{-1}$. The yield from the study area compare favourably with cowpea yields produced elsewhere such as Mokwa and Bida (Afun et al., 1991) and Calabar (Emosairue and Ubana, 1998) although, the chemical applied in this case was neem seed kernel extract (NSKE), a nonconventional chemical. The yields support earlier reports that cowpea yield is increased when treated with synthetic chemicals and unprotected plots usually have the lowest yields. The data also suggested that Asaba ecological zone favours cowpea production. Probably the soil (sandy loam) and climatic factors - low rainfall and fairly warm weather could be responsible for the high yields. Moreover, the calendar schedules - the 7 days' and 10 days' sprays and monitored spray produced yields that support the report from earlier cowpea researchers. The results give credence to earlier reports that monitored spray is as beneficial as 7 and 10 days' sprays.

Except the number of pods per plant, pod load, pod damage and pod evaluation index (Ipe), all other yield related components were not significantly different from the control. Possibly, the insect pest load increased when chemical application had ended in the various treatments and cowpea pods were still green and not fully dried.

Comparing grain yield in the early and late seasons under cypermethrin application, grain yield in the early season at Asaba was $698.70 \mathrm{~kg} \mathrm{ha}^{-1}$ and $741.40 \mathrm{~kg} \mathrm{ha}^{-1}$ in the late season. The yields were slightly higher in the late season, though not significantly different for both seasons. The study showed that high grain yield under the application of CPM in both seasons is possible at Asaba.

Cypermethrin application for cowpea production has been reported in the late season from Calabar by Emosairue et al. (1994). From the data, cowpea yield was high and nearly similar in both seasons. However, cowpea cultivation should take place preferably in the late season, so that the problem of drying is largely removed. Much of the grains usually go bad in the wet season because of the relatively high humidity. The yield related components in the late season had better values for 100 seed weights, number of pods per plant, pod load and pod evaluation index. These values could have contributed to the higher yields envisaged in the late season. Apart from pod length and number of seeds per pod which had higher values in the early season, all other components were similar. Further, more the lower value for seeds with feeding lesion in the late season enhanced better quality of grains, supporting the late season as a more favourable period for cowpea planting in this region.

\section{CONCLUSION}

The study noted that insect number and grain yield during each season were similar under calendar and monitored application of insecticides and second, grain yields were higher during the early planting season than late, in the study area. The study recommends the study area (Asaba) for large scale cowpea cultivation. 


\section{REFERENCES}

Adams, M.W. (1984) Cowpea production constraint and national programmes. Bean / Cowpea Collaborative Research Support Programmes. Michigan State University.

Afun, J.V.K., Jackai, L.E.N. and Hodgson, C.J. (1991) Calendar and monitored insecticide application for the control of cowpea pests. Crop Protection 10: 363-370.

Alabi, O.Y., Odebiyi, J.A. and Jackai, L.E.N. (2003) Field evaluation of cowpea cultivars (Vigna unguiculata (L) Walp.) for resistance to flower bud thrips (Megalurothrips sjostedti Trybom) Thysanoptera: Thripidae) International Journal of Pest Management. 49 (4), 287-291.

Alghali, A.M. (1991) Studies on cowpea farming practices in Nigeria with emphasis on insect pest control. Tropical Pest Management, 37, 71-74.

Anderson, J.W. (1985) Cholesterol lowering effects of canned beans for hypercholestrolmic, Med. Clin. Res. 33(4), 871.

Degri, M. M. and Hadi, H. M. (2000) Field evaluation and economies of some insecticides against the major insect pests of cowpea (Vigna unguiculata (WALP) in Bauchi, Nigeria. ESN Occasional Publication 32 (113118)

Dina, S. O. (1982) Interactions between rate, spray interval and number of applications of the synthetic pyrethroid Decis in Cowpea (Vigna unguiculata) pest control. J. Agric, Camb. 99. 471-478

Dolvo, F.E., Williams, C.E. and Soaka, L. (1976) "Cowpeas. Home preparation and use in W. Africa." International Development Research Centre, Ottawa.

Ejiga, N.O. (1979) The efficiency of the indigenous food grain marketing systems in Nigeria, Savannah Dec., 8 (2), 70-83

Emosairue, S. O., Eze, D. E. and Okore, I. K.(1994) Timing of insecticidal application in Vigna unguiculata (L) Walp, CV.IT84S-2246-4 and its potential as late season crop in the Calabar area. Journal of Applied Chemistry and Agricultural Resource. 1 (1), 6-11.

Emosairue, S. O. and Ubana, U. B. (1998) Field evaluation of neem for the control of some cowpea insect pests in Southern Nigeria. Global Journal of Pure and Applied Science. 4, 237-241

Emosairue, S. O., G.E. Nwofia, S.B.A. Umuetok (2004). Observation on the Insect complex associated with cowpea (Vigna unguiculata) (L.) Walp in Umudike, South-eastern Nigeria J. Sustain. Agric. Environ. 6(1): 38-43.

FOS (1995) Annual Abstract of statistics, Lagos, Nigeria.

IITA (1983) Annual Report for 1982. Ibadan, Nigeria
IITA (1984) Annual Report for 1982. Ibadan, Nigeria

Isubikalu, P. (1998). Understanding farmer knowledge of cowpea production and pest Management; a case study of Eastern Uganda. M. Sc Thesis, Makerere University, Uganda. 158pp.

Jackai, L.E.N. (1983) Efficacy of insecticide applications at different times of day against the legume pod borer, Maruca vitrata (Fab) (Lepidoptera: pyralidae) on cowpea in Nigeria. Production Ecology 5. 245-251.

Jackai, L.E.N. (1985) Cowpea Entomology Research at IITA and its impact on food production in the tropics. Nigeria J. Ent. 6, 87-97.

Jackai, L.E.N. and Daoust, R.A. (1986). Insect pests of cowpeas. Annual Review of Entomology 3195119.

Jackai, L.E,N., Roberts, J.M.F. and Singh, S.R. (1988) Cowpea seed treatment with carbosulfan potential for control of seedling pests. Crop Protection 7: 384-390.

Jackai, L.E.N. (1993). The use of neem in controlling cowpea pests. IITA Research No. 7,5-11.

Jackai, L.E.N., and Oyediran, I. (1991) The potential of neem, Azadirachta indica A. Juss., for the controlling post- flowering pests of cowpea, Vigna ungiuculata Walp. I. The pod borer, Maruca vitrata - Insect Science and its application 12: 103-109

Jackai, L.E.N. and Singh, S.R. (1988) Screening Techniques for Host Plant Resistance to Insect Pests of cowpea. Tropical Grain Legume Bulletin 35: 2-18

Job, T.A., Manner, J.H. and Buitrago, J. (1983) Nigerian Journal of Nutritional Sciences, 4 (1), 29-34.

Johnson, D.E. Kelly, A. and Dorriham, P.P. (1983) Losses of pectic substances during cooking and the effect of watter hardness, J. Sci. Food Agric., 34, 733-736.

Karungi, J., Adipala, E., Ogenga-latigo, M.W., Kyamanywa, S. and Oyobo, N. (2000) Pest management in cowpea. Part 1. Influence of planting time and plant density on cowpea field pests infestation in eastern Uganda. Crop Prot. 19, 231-136.

King, J., Nnanyelugo, D.O., Ene-Obong, H.N. and Ngoddy, P.O. (1985). Household consumption profile of cowpeas (Vigna unguiculata) among low-income families in Nigeria. Ecol. Food and Nutri 16: 209-221.

Litsinger, J.A., Quirino, C.B., Lumaban, M.D. and Bandong, J.P. (1977) Grain Legume Pest Complex of Three Phillipine Rice-Based Cropping System. Cropping Program, IRRI, Los Banos. Philippines, 39.

Ofuya, T. I. (1989) Effect of weeds on colonization of cowpea by Aphis craccivora Koch (Homoptera: Aphididae and its major predators in Nigeria. Tropical Pest Management, 35(4) 403-405.

Okigbo, B.N. (1978) Grain legumes in the agriculture of the tropics. In Pests of Grain legumes Ecology and control 
(Edited by Singh S.R. Van Emden H.E. and Taylor T.A.) Academic Press, Inc., New York.

Olatunde, J.A. Odebiyi, Chiang, H.S. and Jackai, L.E.N. (1991) Identification of sources of resistance in cowpea, Vigna unguiculata L. Walp. to Clavigralla tomentosicollis. Stal. (Hemipera: Coreidae) Insect Sci. Applic., 12 (4), 455-461

Omongo, C. A., Adipala, E., Ogenga Latigo, M. W., Kyamanywa, S. (1998) Insecticide application to reduce pest infestation and damage on cowpea in Uganda. Afri. Plant Prot. 4 (2), 91-100

Remison, S.U. (1978e) Cowpea agronomy works at National Cereals Research Institute. Paper presented at the 1st National meeting. On development of package. Recommendations for legume crops at N.C.R.I, Ibadan, 7-8 February.

Singh, S.R. and Jackai, L.E.N. (1985) Insect pests of cowpeas in Africa: their life cycle, economic importance and potential for control. Pages 217-231 in cowpea research production and utilization, edited by S.R. Singh and K.O. Rachie. John Wiley and Sons, N.Y.

Singh, S.R. and Van emdem, H.F. (1979) Insect pests of grain legumes. Annual Reviews of Entomology 24, pp. 255-278.

Stern V. M. (1973). Economic threshholds. A. Rev. Entomol. 18. 259-280.

Suh, J.B., Jackai, L.E.N. and Hammond, W.N.O. (1986) Observations on pod sucking bug populations on cowpea at Mokwa, Nigeria. Tropical Grain legume Bulletin 33: 17-19.

William, C.E.A. (1974). Preliminary study of consumer preferences in the choice of coepwas. Western and Kwara State Headquarters and Areas of Nigeria Dept. of Agric. Econs. and Ext., University of Ibadan, Nigeria. 